\title{
Dimethylamine Dehydrogenase from Hyphomicrobium X: Purification and Some Properties of a New Enzyme that Oxidizes Secondary Amines
}

\author{
By J. B. M. MEIBERG AND W. HARDER \\ Department of Microbiology, Biological Centre, University of Groningen, \\ Kerklaan 30, 9751 NN Haren, The Netherlands
}

(Received 28 March 1979)

\begin{abstract}
Dimethylamine dehydrogenase was purified 15.6-fold from Hyphomicrobium X grown anaerobically on dimethylamine as sole carbon source by ammonium sulphate fractionation and chromatography on DEAE-cellulose. The preparation was free from trimethylamine dehydrogenase. The molecular weight of the enzyme was 176000 and subunit analysis by sodium dodecyl sulphate-polyacrylamide gel electrophoresis indicated that it consists of two, probably identical, subunits with molecular weights of 91000 . The absorption spectrum showed a maximum at $441 \mathrm{~nm}$. Reduction of the enzyme with dimethylamine produced a new absorption maximum at $356 \mathrm{~nm}$, while the absorption at $441 \mathrm{~nm}$ decreased. The $\mathrm{pH}$ optimum for the oxidation of dimethylamine was $8 \cdot 1$. In this reaction, stoicheiometric amounts of methylamine and formaldehyde were formed as products. The enzyme showed absolute specificity towards secondary amines; dimethylamine, methylethylamine, diethylamine, methylpropylamine, ethylpropylamine and methylethanolamine were oxidized while primary and tertiary amines and quaternary ammonium salts were not. Apart from phenazine methosulphate, only phenazine ethosulphate, Wurster's blue and methylene blue served as artificial electron acceptors. The apparent $K_{\mathrm{m}}$ of the enzyme for dimethylamine at $\mathrm{pH} 7.7$ was $15.6 \pm 1.6 \mu \mathrm{M}$. Trimethylamine was a potent competitive inhibitor of dimethylamine oxidation with an apparent $K_{1}$ of $7 \cdot 1 \mu \mathrm{M}$. This inhibition of dimethylamine dehydrogenase by trimethylamine probably explains the observed accumulation of dimethylamine during anaerobic growth of Hyphomicrobium $\mathrm{X}$ on trimethylamine.
\end{abstract}

\section{INTRODUCTION}

Earlier reports on the oxidation of dimethylamine in aerobic methylotrophic microorganisms have implicated a secondary amine mono-oxygenase (EC 1.14.99.-) as a key enzyme. This enzyme was first reported in Pseudomonas aminovorans by Eady \& Large (1969) and subsequently detected in other organisms capable of growth on methylated amines (Myers \& Zatman, 1971; Colby \& Zatman, 1973). Among the hyphomicrobia that can utilize tertiary and secondary methylated amines, Hyphomicrobium vulgare NQ (Eady et al., 1971) and $H$. vulgare ZV (Loginova et al., 1976) were found to contain dimethylamine mono-oxygenase.

Recently, it was shown that during anaerobic growth of Hyphomicrobium X on trimethylamine and dimethylamine in the presence of nitrate, dimethylamine is oxidized by a dimethylamine dehydrogenase (Meiberg \& Harder, 1978). The evidence indicated that this was a new enzyme. There have been previous reports on dimethylamine dehydrogenase activity, but these refer to the ability of purified trimethylamine dehydrogenase to oxidize the substrate at low rates (Colby \& Zatman, 1974; Steenkamp et al., 1978d; Meiberg \& Harder, 1978). 
In the present paper, the general properties of a partially purified dimethylamine dehydrogenase from Hyphomicrobium $\mathrm{X}$ are described. Special attention is paid to those kinetic parameters which might explain the rather complicated pattern of substrate utilization which occurs during anaerobic growth of this organism on trimethylamine (Meiberg \& Harder, 1978).

\section{METHODS}

Maintenance and growth of the organism. These have been described previously (Meiberg \& Harder, 1978). Purification of dimethylamine dehydrogenase. This procedure was essentially as described by Meiberg \& Harder (1978), but with some modifications to improve the separation of dimethylamine dehydrogenase from the contaminating trimethylamine dehydrogenase. The active ammonium sulphate fraction ( 50 to $80 \%$ saturation) was dialysed and then applied to a column of DEAE-cellulose (Whatman, DE52). Protein was eluted with a linear salt gradient of 0 to $0.3 \mathrm{M}-\mathrm{NaCl}$ in $20 \mathrm{~mm}$-sodium phosphate buffer, $\mathrm{pH} 7.5$ (a total volume of $400 \mathrm{ml}$ ); the flow rate was $10 \mathrm{ml} \mathrm{h}^{-1}$. The fractions containing dimethylamine dehydrogenase activity without any trimethylamine dehydrogenase were pooled and concentrated by ultrafiltration.

Enzyme assays. Dimethylamine dehydrogenase was measured with an anaerobic spectrophotometric assay (Meiberg \& Harder, 1978) which was slightly modified for optimal results. The reaction mixture contained (in $1 \mathrm{ml}$ ) $75 \mu \mathrm{mol}$ sodium pyrophosphate buffer $\mathrm{pH} 7 \cdot 7,0 \cdot 10 \mu \mathrm{mol}$ 2,6-dichlorophenolindophenol (DCPIP), $2.5 \mu \mathrm{mol}$ phenazine methosulphate (PMS) and purified enzyme; the reaction was started by adding $3 \mu \mathrm{mol}$ dimethylamine. In the kinetic experiments, the concentration of one reactant was changed, while the concentrations of the other reactants were kept constant.

Oxygen-uptake was measured with a Clark-type oxygen electrode (Biological Oxygen Monitor, Yellow Springs Instrument Co., U.S.A.). The air-saturated assay mixture was similar to that described before, except that the total volume in the electrode chamber was $3 \mathrm{ml}$ and DCPIP was omitted from the reaction mixture.

Trimethylamine dehydrogenase (EC 1.5.99.7) was measured spectrophotometrically in a reaction mixture similar to that used for the dimethylamine dehydrogenase, but with $3 \mathrm{~mm}$-trimethylamine as the substrate.

Catalase (EC 1.11.1.6) was measured according to the procedure of Lück (1963).

Malate dehydrogenase (EC 1.1.1.37) was assayed as described by Bergmeyer (1974).

Molar absorption coefficients of electron acceptors. These were taken as: DCPIP at $600 \mathrm{~nm}$ and at $\mathrm{pH} 7 \cdot 7$, $21.69 \times 10^{3} \mathrm{M}^{-1} \mathrm{~cm}^{-1}$ (Armstrong, 1964); reduced cytochrome $c$ at $550 \mathrm{~nm}, 21.0 \times 10^{3} \mathrm{M}^{-1} \mathrm{~cm}^{-1}$, NADH and NADPH at $340 \mathrm{~nm}, 6 \cdot 22 \times 10^{3} \mathrm{M}^{-1} \mathrm{~cm}^{-1}$, and $\mathrm{K}_{3} \mathrm{Fe}(\mathrm{CN})_{6}$ at $400 \mathrm{~nm}, 1.02 \times 10^{3} \mathrm{M}^{-1} \mathrm{~cm}^{-1}$ (Colby \& Zatman, 1974); Wurster's blue at $612 \mathrm{~nm}, 8.29 \times 10^{3} \mathrm{M}^{-1} \mathrm{~cm}^{-1}$.

Molecular weight determination. The molecular weight of the dimethylamine dehydrogenase was estimated by gel filtration on Sephadex G-200 (Andrews, 1970). Ferritin ( $540000 \mathrm{~mol}$. wt), catalase (240000), bovine serum albumin dimer (136000) and monomer (68000), malate dehydrogenase (70000), ovalbumin (45000), chymotrypsinogen A (25000) and cytochrome $c$ (12500) were used as standards.

Polyacrylamide gel electrophoresis. Electrophoresis was performed on $7.0 \%(\mathrm{w} / \mathrm{v})$ acrylamide gels in Tris/HCl buffer $\mathrm{pH} 8.9$ according to the procedure of Davis (1964). Electrophoresis was conducted at room temperature at $4 \mathrm{~mA}$ per tube for $1.5 \mathrm{~h}$. Proteins were stained in $0.25 \%(\mathrm{w} / \mathrm{v})$ Coomassie blue in $45.4 \%$ (v/v) methanol $/ 0.92 \%(\mathrm{v} / \mathrm{v})$ acetic acid for $1 \mathrm{~h}$ and destained in $5 \%(\mathrm{v} / \mathrm{v})$ methanol/7.5\% $(\mathrm{v} / \mathrm{v})$ acetic acid.

Enzyme activity in the gels was detected by coupling the oxidation of substrates with the reduction of 3-(4,5-dimethylthioazol-2-yl)-2,5-diphenyl-2H-tetrazolium bromide (MTT). The reaction mixture contained $0.5 \mathrm{ml} 0.15 \mathrm{M}$-sodium pyrophosphate buffer $\mathrm{pH} 7.7,1 \mathrm{ml} \mathrm{0.1 \% (w/v)} \mathrm{MTT,} 0.1 \mathrm{ml} 150 \mathrm{mM}$-dimethylamine or trimethylamine, gel and water up to $5 \mathrm{ml}$. Incubation was at room temperature for 5 to $15 \mathrm{~min}$ in the dark.

Sodium dodecyl sulphate (SDS)-gel electrophoresis was performed using $7.5 \%(\mathrm{w} / \mathrm{v})$ acrylamide gels in the presence of $0.1 \%(\mathrm{w} / \mathrm{v})$ SDS according to the procedure of Weber et al. (1972). The enzyme preparation and other protein samples which were used as molecular weight markers were incubated in $0.01 \mathrm{M}$-sodium phosphate buffer pH 7.0, containing $1 \%(\mathrm{w} / \mathrm{v}) \mathrm{SDS}$ and $1 \%(\mathrm{w} / \mathrm{v}) 2$-mercaptoethanol at $100{ }^{\circ} \mathrm{C}$ for $2 \mathrm{~min}$ prior to electrophoresis. The subunit molecular weights of the marker proteins were: cytochrome $c, 12500$; aldolase, 40000; catalase, 58000; bovine serum albumin, 68000; $\beta$-galactosidase (Escherichia coli), 130000 .

Absorption spectra. These were measured in an Aminco-Chance model DW-2 spectrophotometer, operating in the split-beam mode. The enzyme preparation was dissolved in air-saturated $75 \mathrm{~mm}$-sodium pyrophosphate buffer $\mathrm{pH}$ 7.7. Additional oxidation of the preparation was allowed by saturating the enzyme solution with air. Subsequent reduction of the enzyme was performed by adding dimethylamine or sodium dithionite.

Estimation of methylated amines. These were measured as described previously (Meiberg \& Harder, 1978) with the following modifications: (i) a Packard gas chromatograph model 427 was used; (ii) a soda-lime 
pre-column was fitted in the injection block at a temperature of $180^{\circ} \mathrm{C}$ in order to release the free amines from their salts.

Estimation of formaldehyde. It was difficult to estimate formaldehyde in the dimethylamine dehydrogenase reaction mixture in studies on the stoicheiometry of the reaction because of interference by PMS or insensitivity of the various methods. For these reasons, neither the colorimetric method of Nash (1953) nor enzymic assays with alcohol oxidase from Candida boidinii or alcohol dehydrogenase from yeast could be used. However, the colorimetric method described by Colby \& Zatman (1974) gave reproducible results provided that the time of colour development was kept constant.

Chemicals. $N$-Methylethylamine hydrochloride was obtained from Eastman Kodak Co., U.S.A. $N, N$ Diethylmethylamine and $N$-ethyldimethylamine were from Fluka, Buchs, Switzerland. $N$-Methyl- $n$-propylamine, $N$-ethyl- $n$-propylamine and $N$-methyl- $n$-butylamine were gifts from $\mathrm{Dr}$ P. J. Large, University of Hull. $N, N$-Dimethylethanolamine and unsymmetrical dimethylethylenediamine were from Aldrich Europe, Belgium. All other amine compounds were from Merck. The purity of the substrates was checked in the gas chromatograph under the conditions described previously. In all cases, except methylethylamine, the amount of contaminating substrates present was negligible and could not account for the activities recorded; methylethylamine contained significant amounts of non-oxidizable ethylamine. Biochemicals and enzymes were from Boehringer, Wurster's blue, prepared as described by Michaelis \& Granick (1943), was a gift from Dr J. A. Duine, Technische Hogeschool, Delft, The Netherlands.

\section{RESULTS}

\section{Partial purification of dimethylamine dehydrogenase}

Recently, Meiberg \& Harder (1978) reported the partial purification of trimethylamine and dimethylamine dehydrogenases from Hyphomicrobium X. However, complete separation of the two enzymes was not obtained. An improved procedure for the purification of the dimethylamine dehydrogenase, as described in Methods, was developed and resulted in an enzyme preparation which was devoid of trimethylamine oxidizing activity. A summary of the enzyme purification is presented in Table 1. A 14-fold purification was achieved by ammonium sulphate fractionation followed by DEAE-cellulose column chromatography. When the concentrated enzyme preparation was kept at $0{ }^{\circ} \mathrm{C}$ for $14 \mathrm{~d}$, a protein precipitate developed which was discarded. The final enzyme preparation, which was purified $15 \cdot 6$-fold, had a yellow-brown colour. The recovery was $43 \%$.

The purity of the enzyme was checked by polyacrylamide disc gel electrophoresis, using $7 \%$ acrylamide in $\mathrm{Tris} / \mathrm{HCl}$ buffer $\mathrm{pH} 8.9$. The partially purified enzyme ( $80 \mu \mathrm{g}$ protein) gave one major and three minor bands. Only the major band showed dimethylamine dehydrogenase activity; the $R_{F}$ value of the enzyme was 0.51 . On the basis of the above polyacrylamide gel electrophoresis, impurities in the preparation were estimated to account for less than $10 \%$ of the total protein applied to the gel. The preparation was essentially free from trimethylamine dehydrogenase, methanol dehydrogenase and catalase and was therefore suitable for stoicheiometric and kinetic studies.

\section{Properties of dimethylamine dehydrogenase}

Effect of freezing on stability. Freezing of the enzyme preparation in liquid nitrogen resulted in a complete loss of activity. Attempts to stabilize the enzyme in $20 \%(\mathrm{w} / \mathrm{v})$ glycerol or $80 \%$ ammonium sulphate were unsuccessful. After freezing once, the activity of the enzyme was decreased to $40 \%$ of its initial activity. Storage at $0{ }^{\circ} \mathrm{C}$ for 3 months resulted in the loss of $50 \%$ of the initial activity. However, similar to the observations made with trimethylamine dehydrogenase (Steenkamp \& Mallinson, 1976), dimethylamine dehydrogenase was stabilized by ethylene glycol. Enzyme preparations kept at $-10{ }^{\circ} \mathrm{C}$ in the presence of $20 \%(\mathrm{v} / \mathrm{v})$ ethylene glycol retained full activity for at least 3 months.

Molecular weight and subunit molecular weight. The molecular weight of the dimethylamine dehydrogenase, as determined by gel filtration, was 176000 . When the enzyme was treated with $1 \%$ SDS in $0.01 \mathrm{M}$-sodium phosphate buffer $\mathrm{pH} 7.0$ and subjected to SDS-polyacrylamide gel electrophoresis, a single protein band was observed. The relative electrophoretic mobility of the protein corresponded to a subunit with a molecular weight of 
Table 1. Purification of dimethylamine dehydrogenase from Hyphomicrobium $\mathrm{X}$

Total activities are expressed as nmol substrate transformed $\mathrm{min}^{-1}$ and specific activities as nmol substrate transformed $\min ^{-1}$ (mg protein) $)^{-1}$.

\begin{tabular}{|c|c|c|c|c|c|c|}
\hline Fraction & $\begin{array}{l}\text { Vol. } \\
\text { (ml) }\end{array}$ & $\begin{array}{l}\text { Total } \\
\text { protein } \\
\text { (mg) }\end{array}$ & $\begin{array}{c}\text { Total } \\
\text { activity }\end{array}$ & $\begin{array}{l}\text { Specific } \\
\text { activity }\end{array}$ & $\begin{array}{c}\text { Recovery } \\
(\%)\end{array}$ & $\begin{array}{l}\text { Purification } \\
\text { factor }\end{array}$ \\
\hline Crude cell-free extract & 25 & $245 \cdot 5$ & $5739 \cdot 8$ & $23 \cdot 4$ & 100 & 1 \\
\hline $\begin{array}{l}\text { Ammonium sulphate } \\
\text { fraction } 50 \text { to } 80 \% \\
\text { saturation }\end{array}$ & $3 \cdot 7$ & $125 \cdot 7$ & $4741 \cdot 4$ & $37 \cdot 7$ & 82.6 & 1.6 \\
\hline DEAE-cellulose eluate* & 9.95 & $8 \cdot 0$ & $2616 \cdot 0$ & $327 \cdot 0$ & $45 \cdot 6$ & $14 \cdot 0$ \\
\hline Concentrated DEAE- & $9 \cdot 8$ & 6.8 & $2473 \cdot 8$ & $363 \cdot 8$ & $43 \cdot 1$ & $15 \cdot 6$ \\
\hline
\end{tabular}

* Assayed after concentration by ultrafiltration.

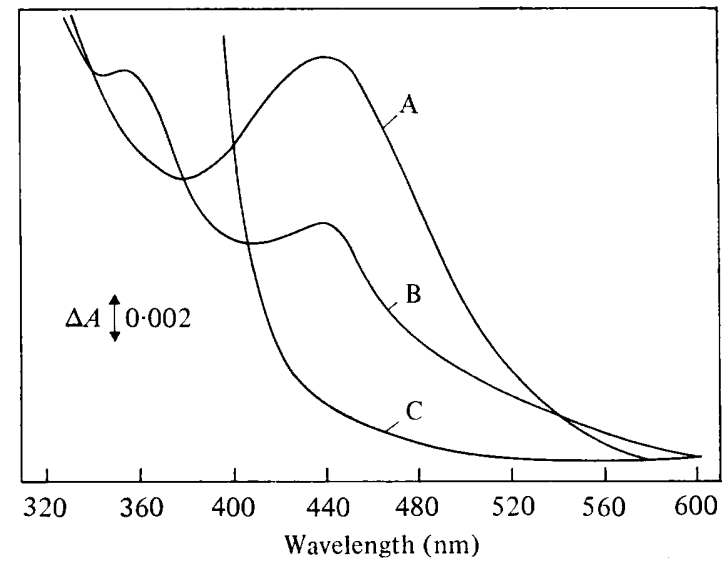

Fig. 1. Absorption spectrum of dimethylamine dehydrogenase. The enzyme concentration was $0.16 \mathrm{mg}$ protein $\mathrm{ml}^{-1}$ in $75 \mathrm{~mm}$-sodium pyrophosphate buffer $\mathrm{pH} 7.7$ : curve $\mathrm{A}$, oxidized enzyme; curve B, after addition of $3 \mathrm{~mm}$-dimethylamine; curve $\mathrm{C}$, after addition of a crystal of solid sodium dithionite to $\mathbf{B}$.

91000. This value is half the molecular weight of the native enzyme, suggesting that the dimethylamine dehydrogenase consists of two subunits of equal size.

Absorption spectrum. The visible spectrum of dimethylamine dehydrogenase in airsaturated buffers is shown in Fig. 1. The oxidized enzyme had an absorption maximum at $441 \mathrm{~nm}$ (curve A). Addition of dimethylamine to the purified enzyme caused a decrease in the absorption at $441 \mathrm{~nm}$ and produced an absorption peak at $356 \mathrm{~nm}$ (curve B). The peak at $441 \mathrm{~nm}$ was bleached completely by the addition of solid sodium dithionite (curve $\mathrm{C}$ ).

Effect of $p H$ on activity. The $\mathrm{pH}$ optimum curve for enzyme activity exhibited a symmetrical pattern. The optimum $\mathrm{pH}$ in $75 \mathrm{~mm}$-sodium pyrophosphate buffer was $8 \cdot 1$. The behaviour of the enzyme in other buffer systems was not tested. At $\mathrm{pH}$ values above $7 \cdot 7$, the nonenzymic reduction of DCPIP became substantial and made the measurement of initial rates difficult. For this reason, subsequent experiments were done at a suboptimal $\mathrm{pH}$ of 7.7. For the calculation of the enzyme activity, the dependence of the molar absorption coefficient of DCPIP on pH (Armstrong, 1964) was taken into account.

Influence of PMS and DCPIP on enzyme activity. PMS could serve as an artificial primary electron acceptor for the dimethylamine dehydrogenase. The initial velocity of the enzyme reaction was maximal at $2.4 \mathrm{~mm}-\mathrm{PMS}$; above this concentration, PMS inhibited enzyme 




Fig. 2. Substrate consumption and product formation by dimethylamine dehydrogenase. The complete reaction mixture (total vol. $0.4 \mathrm{ml}$ ) contained $30 \mu \mathrm{mol}$ sodium pyrophosphate buffer $\mathrm{pH} 7 \cdot 7,1 \mu \mathrm{mol}$ PMS, $28 \mu \mathrm{g}$ enzyme protein and $0 \cdot 8 \mu \mathrm{mol}$ dimethylamine. $\bigcirc$, Dimethylamine; , methylamine; $\square$, formaldehyde.

activity. The apparent $K_{\mathrm{m}}$ for PMS was $1 \cdot 18 \mathrm{~mm}$ at $\mathrm{pH} 7 \cdot 7$. At the optimum PMS concentration, the enzyme activity at various DCPIP concentrations showed a saturation curve with maximum activity at $100 \mu \mathrm{M}$. This concentration was used for further studies.

Product identification. Incubation of dimethylamine dehydrogenase with dimethylamine as substrate and PMS as electron acceptor resulted in a disappearance of dimethylamine with concurrent production of methylamine and formaldehyde (Fig. 2). Dimethylamine $(0.80 \mu \mathrm{mol})$ was quantitatively converted into $0.81 \mu \mathrm{mol}$ methylamine and $0.84 \mu \mathrm{mol}$ formaldehyde. In oxygen-uptake assays (performed in the presence of catalase) the oxidation of $0.6 \mu \mathrm{mol}$ dimethylamine corresponded to an oxygen consumption of $0.29 \mu \mathrm{mol}$. These results are consistent with the following stoicheiometry of dimethylamine oxidation by dimethylamine dehydrogenase:

$$
\begin{aligned}
\left(\mathrm{CH}_{3}\right)_{2} \mathrm{NH}+\mathrm{PMS}+\mathrm{H}_{2} \mathrm{O} & \rightarrow \mathrm{CH}_{3} \mathrm{NH}_{2}+\mathrm{PMSH}_{2}+\mathrm{HCHO} \\
\mathrm{PMSH}_{2}+\mathrm{O}_{2} & \rightarrow{\mathrm{PMS}+\mathrm{H}_{2} \mathrm{O}_{2}}_{\mathrm{H}_{2} \mathrm{O}_{2}} \rightarrow \mathrm{H}_{2} \mathrm{O}+\frac{1}{2} \mathrm{O}_{2} \\
\hline\left(\mathrm{CH}_{3}\right)_{2} \mathrm{NH}+\frac{1}{2} \mathrm{O}_{2} & \rightarrow \mathrm{CH}_{3} \mathrm{NH}_{2}+\mathrm{HCHO}
\end{aligned}
$$

Substrate specificity. The purified dimethylamine dehydrogenase was highly specific for secondary amines as substrate (Table 2 ). Neither primary nor tertiary amines nor quaternary ammonium compounds were oxidized. Oxidation of secondary methylalkylamines was limited to dimethyl-, methylethyl- and methylpropylamine. Increased chain length of the alkyl group in methylalkylamines caused a decrease in activity. The highest activity was observed with dimethylamine, the lowest with methylpropylamine, whereas methylbutylamine was not oxidized at all. The gradual decrease in activity with increase in chain length suggests an increasing steric hindrance for the enzyme to oxidize methyl groups. The enzyme showed strong preference for oxidation of methyl groups because oxidation of methylethylamine yielded ethylamine; formation of methylamine as a result of the oxidation of the ethyl group of methylethylamine was not observed. However, since the enzyme showed a high activity with diethylamine as a substrate it is clearly capable of oxidizing ethyl groups. The enzyme reacted slowly with ethylpropylamine. Dipropylamine did not serve as a substrate for the enzyme, indicating that dimethylamine dehydrogenase may be restricted to oxidative demethylation or de-ethylation of secondary amines. 


\section{Table 2. Substrate specificity of dimethylamine dehydrogenase}

Substrate solutions were adjusted to $\mathrm{pH} 7 \cdot 7$ before addition. Each compound was tested at two concentrations ( 1 and $10 \mathrm{~mm}$ ); the concentration given in parentheses gave the maximum rate. Activities are expressed as a percentage of the activity obtained with $1 \mathrm{~mm}$-dimethylamine.

Substrate

Dimethylamine (1 mM), $\mathrm{CH}_{3} \mathrm{NHCH}_{3}$ Methylethylamine (1 mM), $\mathrm{CH}_{3} \mathrm{NHCH}_{2} \mathrm{CH}_{3}$ Diethylamine (1 mM), $\mathrm{CH}_{3} \mathrm{CH}_{2} \mathrm{NHCH}_{2} \mathrm{CH}_{3}$ Methylpropylamine (1 mM), $\mathrm{CH}_{3} \mathrm{NHCH}_{2} \mathrm{CH}_{2} \mathrm{CH}_{3}$ Ethylpropylamine (10 mM), $\mathrm{CH}_{3} \mathrm{CH}_{2} \mathrm{NHCH}_{2} \mathrm{CH}_{2} \mathrm{CH}_{3}$ Methylethanolamine (1 mM), $\mathrm{CH}_{3} \mathrm{NHCH}_{2} \mathrm{CH}_{2} \mathrm{OH}$
Relative activity

100

$92 \cdot 1$

$78 \cdot 3$

$12 \cdot 9$

$6 \cdot 8$

$54 \cdot 2$

The following compounds were not oxidized: methylamine, trimethylamine, tetramethylammonium chloride, ethylamine, triethylamine, tetraethylammonium chloride, propylamine, dipropylamine, dibutylamine, dimethylethylamine, methyldiethylamine, methylbutylamine, ethanolamine, diethanolamine, triethanolamine, dimethylethanolamine, dimethylformamide.

\section{Table 3. Effect of alternative electron acceptors on dimethylamine dehydrogenase activity}

Reactions were recorded with the anaerobic spectrophotometric assay or the oxygen-uptake assay. Activities were calculated from the rate of reduction of the terminal electron acceptor and are expressed as a percentage of the activity obtained with PMS/DCPIP at $600 \mathrm{~nm}$.

$\begin{array}{lcc}\text { Concn } & \text { Relative } \\ \text { Acceptor } & \text { activity }\end{array}$

\begin{tabular}{lcc}
\multicolumn{3}{c}{ Spectrophotometric assay } \\
Wurster's blue & 0.3 & 73.8 \\
PMS (+0.1 mM-DCPIP) & $2 \cdot 5$ & 100 \\
PMS (+0.1 mM-cytochrome c) & 2.5 & 77.6
\end{tabular}

The following electron acceptors were not active: potassium ferricyanide, cytochrome $c$ (horse heart), cytochrome $c_{\mathrm{Co}}$ (Hyphomicrobium X)*, DCPIP, $\mathrm{NAD}^{+}$and $\mathrm{NADP}^{+}$.

$\begin{array}{lcr}\quad \text { Oxygen-uptake assay } & & \\ & & \\ \text { PMS } \dagger & 2 \cdot 5 & 140 \cdot 1 \\ \text { PES } \dagger \text { (phenazine ethosulphate) } & 2 \cdot 5 & 103 \cdot 4 \\ \text { Methylene blue } \dagger & 10 & 17 \cdot 2\end{array}$

No enzyme-dependent oxygen consumption could be measured with $\mathrm{O}_{2}$ (air saturation), menadione, FAD, benzyl viologen and methyl viologen.

* Cytochrome $c_{\mathrm{Co}}$ was isolated from Hyphomicrobium $\mathrm{X}$ as described by Large et al. (1979).

$\uparrow$ Catalase (13000 units) was included in the reaction mixture.

Specificity of dimethylamine dehydrogenase for electron acceptors. Several potential electron acceptors were tested in the spectrophotometric or oxygen-uptake assays (Table 3). Only PMS, PES, Wurster's blue and, to a lesser extent, methylene blue served as primary electron acceptors. Horse heart cytochrome $c$ could replace DCPIP or oxygen as secondary electron acceptor. Cytochrome $c$ alone (either from horse heart or from Hyphomicrobium X) was unable to oxidize the reduced enzyme (Large et al., 1979). The apparent $K_{\mathrm{m}}$ for Wurster's blue was $0 \cdot 11 \mathrm{mM}$.

Influence of trimethylamine and reaction products on dimethylamine oxidation by dimethylamine dehydrogenase. Trimethylamine is a potent inhibitor of dimethylamine dehydrogenase activity. Double-reciprocal plots of dimethylamine concentration against initial velocity with different trimethylamine concentrations in the reaction mixture showed competitive inhibition of dimethylamine dehydrogenase by trimethylamine (Fig. 3). An apparent $K_{\mathrm{i}}$ value for trimethylamine of $7 \cdot 1 \pm 1 \cdot 3 \mu \mathrm{M}$ was calculated from the slopes of the different plots. The apparent $K_{\mathrm{m}}$ for dimethylamine at $\mathrm{pH} 7.7$ in the absence of trimethylamine was estimated to be $15 \cdot 6 \pm 1 \cdot 6 \mu \mathrm{M}$.

Dimethylamine at concentrations up to $3.0 \mathrm{~mm}$ was not inhibitory for the enzyme, but at $10 \mathrm{~mm}$ it caused $23 \%$ inhibition. Freshly prepared formaldehyde did not inhibit dimethyl- 


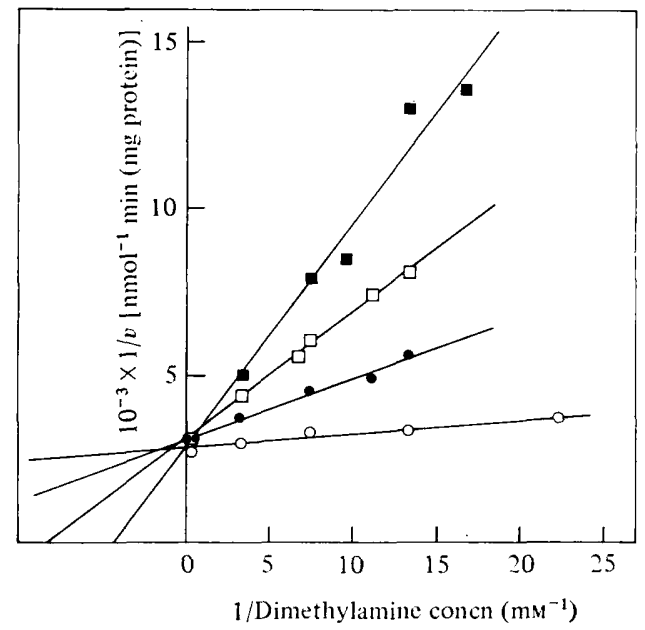

Fig. 3. Inhibition of dimethylamine dehydrogenase by trimethylamine. Reciprocal values of the velocity of the enzyme reaction were plotted against the reciprocal dimethylamine concentration at three concentrations of trimethylamine:, $30 \mu \mathrm{M} ; \square, 60 \mu \mathrm{M} ; \mathbf{\square}, 90 \mu \mathrm{M} ; O$, no inhibitor.

amine dehydrogenase even at unphysiological concentrations of $20 \mathrm{mM}$. Methylamine at $1 \mathrm{~mm}$ did not alter the enzyme activity significantly; at higher concentrations (6 and $17 \cdot 5 \mathrm{~mm}$ ) it was slightly inhibitory.

\section{DISCUSSION}

Hyphomicrobium $\mathrm{X}$ is able to grow anaerobically on trimethylamine and dimethylamine in the presence of nitrate as the terminal electron acceptor. Under these conditions one would not expect the organism to have a functional secondary amine mono-oxygenase. We therefore attempted to detect an enzyme system responsible for the anaerobic conversion of dimethylamine to methylamine and formaldehyde. Indeed, using the assay system of Colby \& Zatman (1973) for the estimation of trimethylamine dehydrogenase, we were able to detect a dimethylamine-dependent reduction of PMS/DCPIP (Meiberg \& Harder, 1976, 1978), and showed that this activity was not due to a dual substrate specificity of the trimethylamine dehydrogenase. The results reported in this paper show that dimethylamine dehydrogenase is a new enzyme. It is not, however, the only dehydrogenase capable of oxidizing dimethylamine, since the trimethylamine dehydrogenases of organisms 4B6 and W3A1 (Colby \& Zatman, 1974; Steenkamp et al., 1978d) can also oxidize dimethylamine, albeit at a low rate. For instance, the enzyme from bacterium 4B6 exhibited a dimethylamine oxidation rate which was only $5 \%$ of the rate with trimethylamine. No pertinent data have been reported for trimethylamine dehydrogenase from bacterium W3A1, but it was stated that the rate of reduction of the enzyme with dimethylamine was much slower than with trimethylamine as the substrate (Steenkamp et al., 1978d). The same, relatively poor, kinetic behaviour with dimethylamine was observed with a partially purified preparation of trimethylamine dehydrogenase from Hyphomicrobium X (Meiberg, 1979). This virtually ruled out a possible role of trimethylamine dehydrogenase in dimethylamine oxidation and it emphasizes the importance of dimethylamine dehydrogenase in Hyphomicrobium X during anaerobic growth on trimethylamine and dimethylamine.

Apart from the difference in kinetic properties, the enzyme resembles the trimethylamine dehydrogenases known so far in many respects. It catalyses the same type of reactions, namely the oxidative $N$-dealkylation (demethylation) of a secondary amine with the formation of stoicheiometric amounts of free (form)aldehyde and primary amine (Fig. 2), and 
its kinetics for PMS and DCPIP are similar to that of trimethylamine dehydrogenase (Colby \& Zatman, 1974; Meiberg, 1979).

The absorption spectrum of the dimethylamine dehydrogenase is identical to the spectrum of the trimethylamine dehydrogenase of bacterium W3A1 (Steenkamp \& Mallinson, 1976) and the trimethylamine dehydrogenase of Hyphomicrobium X (Meiberg, 1979). The spectral changes that occur after reduction of the W3Al enzyme by trimethylamine or dithionite have been studied extensively by Steenkamp and co-workers. They found that the enzyme contains an unusual covalently bound flavin, 6-S-cysteinyl FMN (Steenkamp et al., 1978 a, b) and a single tetrameric iron-sulphur centre (Hill et al., 1977). On the basis of our kinetic studies we cannot draw conclusions about the reaction mechanism, but it is tempting to consider the possibility that the reaction mechanism of dimethylamine dehydrogenase is similar to that described for trimethylamine dehydrogenase by Steenkamp et al. $(1978 c, d)$. It is thus possible that the enzyme is representative of the group of dissimilatory enzymes, common among methylotrophic micro-organisms, which contain unusual cofactors (Anthony \& Zatman, 1967; Eady \& Large, 1968; Duine et al., 1978; Steenkamp et al., 1978b). Of the artificial electron acceptors tested, only PMS, PES, methylene blue and Wurster's blue were active (Table 3). Wurster's blue has also been reported as a one-electron acceptor for the methanol dehydrogenase of Hyphomicrobium X (Duine et al., 1978) and the monomethylamine dehydrogenase of Pseudomonas AM1 (Eady \& Large, 1968). It is the stable oxidized free-radical form of tetramethyl-p-phenylenediamine and has a redox potential of $+0.263 \mathrm{~V}$ (Michaelis \& Hill, 1933) at $\mathrm{pH} 7 \cdot 0$. Dimethylamine dehydrogenase had a relatively low apparent $K_{\mathrm{m}}$ for this compound as compared to PMS. The dye inhibited enzyme activity at concentrations higher than $0.4 \mathrm{~mm}$. Except for Wurster's blue, the $E_{0}^{\prime}$ values of the other active electron acceptors are in the range of +0.011 to $+0.08 \mathrm{~V}$. These data agree with the results of Colby \& Zatman (1974) with purified trimethylamine dehydrogenase from bacterium 4B6. These authors argue that 'the natural electron acceptor has an $E_{0}^{\prime}$ of about or just above zero and, although FAD and FMN were not active as primary electron acceptors, it is quite possible that the natural acceptor is a flavoprotein, because some flavoproteins have $E_{0}^{\prime}$ values of about zero'. Indeed, very recently Steenkamp \& Gallup (1978) reported the isolation and partial characterization of a flavoprotein which probably functions as the electron acceptor in vivo for the trimethylamine dehydrogenase of bacterium W3A1. At present it is not known whether such a flavoprotein also acts as the natural electron acceptor for dimethylamine dehydrogenase. In this connection it is of interest to note that cytochrome $c_{\mathrm{co}}$ is unable to accept the electrons from the oxidation of dimethylamine (Large et al., 1979).

Dimethylamine dehydrogenase has an absolute specificity for secondary amines as substrates (Table 2). This behaviour is similar to that of the secondary amine mono-oxygenase of Pseudomonas aminovorans (Eady et al., 1971) which oxidizes the same range of substrates. Kinetic experiments showed a potent competitive inhibition of dimethylamine oxidation by trimethylamine (Fig. 3). This suggests that the enzyme, although not capable of oxidizing trimethylamine, has a high affinity for this compound, a phenomenon analogous to the inhibition of trimethylamine oxidation by tetramethylammonium chloride (Colby \& Zatman, 1974). This inhibition by trimethylamine most probably explains the accumulation of dimethylamine during anaerobic growth of Hyphomicrobium X on trimethylamine. During growth of the organism under denitrifying conditions an almost stoicheiometric conversion of trimethylamine into dimethylamine was observed, despite the presence of dimethylamine dehydrogenase in the cells (Meiberg \& Harder, 1978). This is probably a result of the initial high trimethylamine concentration in the culture completely inhibiting the oxidation of dimethylamine formed by the action of trimethylamine dehydrogenase. As growth proceeds, the simultaneous decrease in trimethylamine concentration and increase in dimethylamine concentration may then release the inhibition of dimethylamine dehydrogenase by trimethylamine and dimethylamine oxidation starts. 
This hypothesis clearly hinges on the assumption that the dimethylamine dehydrogenase in vivo is in fact exposed to trimethylamine concentrations sufficiently high to cause inhibition. For several reasons (Meiberg, 1979) it appears unlikely that this condition can be reconciled with the possibility that both dehydrogenases are located in the cytoplasm. Although upon extraction by sonication both enzymes were found in the soluble fraction, preliminary results of cytochemical staining experiments suggested that they were membrane-bound. Not only the cytoplasmic membrane but also membranes which are dispersed throughout the cell's interior were shown to contain trimethylamine and dimethylamine dehydrogenase activities. It is almost certain that these membranes are invaginations of the cytoplasmic membrane (Meiberg, 1979). Similar cellular membrane invaginations have been found in Hyphomicrobium B522 (Conti \& Hirsch, 1965). However, in order to explain conclusively the in vivo substrate utilization during growth of Hyphomicrobium $\mathrm{X}$ on trimethylamine under anaerobic conditions by applying the observed inhibition kinetics, it remains to be elucidated whether the dimethylamine dehydrogenase is located in the outside or the inside of the membranes.

We wish to thank Drs M. M. Attwood, P. J. Large and J. P. van Dijken for many valuable discussions.

\section{REFERENCES}

ANDrews, P. (1970). Estimation of molecular size and molecular weight of biological compounds by gel filtration. Methods of Biochemical Analysis 18, $1-53$.

Anthony, C. \& Zatman, L. J. (1967). The microbial oxidation of methanol. The prosthetic group of the alcohol dehydrogenase of Pseudomonas sp. M27: a new oxidoreductase prosthetic group. Biochemical Journal 104, 960-969.

Armstrong, J. McD. (1964). The molar extinction coefficient of 2,6-dichlorophenolindophenol. Biochimica et biophysica acta 86, 194-197.

Bergmeyer, H. U. (1974). Malate dehydrogenase. In Methods of Enzymatic Analysis, 2nd edn, pp. 485-486. Edited by H. U. Bergmeyer. New York, San Francisco \& London: Academic Press.

Colby, J. \& ZATMAN, L. J. (1973). Trimethylamine metabolism in obligate and facultative methylotrophs. Biochemical Journal 132, 101-112.

Colby, J. \& Zatman, L. J. (1974). Purification and properties of the trimethylamine dehydrogenase of Bacterium 4B6. Biochemical Journal 143, 555-567.

ConTI, S. F. \& Hirsch, P. (1965). Biology of budding bacteria. III. Fine structure of Rhodomicrobium and Hyphomicrobium spp. Journal of Bacteriology 89, 503-512.

Davis, B. J. (1964). Disc electrophoresis. II. Methods and application to human serum proteins. Annals of the New York Academy of Sciences 121, 404-427.

Duine, J. A., Frank, J. \& Westerling, J. (1978). Purification and properties of methanol dehydrogenase from Hyphomicrobium X. Biochimica et biophysica acta 524, 277-287.

EADY, R. R. \& LARGe, P. J. (1968). Purification and properties of an amine dehydrogenase from Pseudomonas AM1 and its role in growth on methylamine. Biochemical Journal 106, 245-255.

EADY, R. R. \& LARGE, P. J. (1969). Bacterial oxidation of dimethylamine, a new mono-oxygenase reaction. Biochemical Journal 111, 37P-38P.

EADY, R. R., JARMAN, T. R. \& LARGE, P. J. (1971).
Microbial oxidation of amines. Partial purification of a mixed-function secondary-amine oxidase system from Pseudomonas aminovorans that contains an enzymically active cytochrome- $P$-420-type haemoprotein. Biochemical Journal 125, 449-459.

Hill, C. L., Steenkamp, D. J., Holm, R. H. \& Singer, T. P. (1977). Identification of the ironsulfur center in trimethylamine dehydrogenase. Proceedings of the National Academy of Sciences of the United States of America 74, 547-551.

Large, P. J., Meiberg, J. B. M. \& Harder, W. (1979). Cytochrome $c_{\mathrm{Co}}$ is not a primary electron acceptor for the amine dehydrogenases of Hyphomicrobium X. FEMS Microbiology Letters 5, 281286.

Loginova, N. V., Shishkina, V. N. \& Trotsenko, YU. A. (1976). Primary metabolic pathways of methylated amines in Hyphomicrobium vulgare. Mikrobiologiya (English translation) 45, 34-40.

LücK, H. (1963). Catalase. In Methods of Enzymatic Analysis, 1st edn, pp. 885-894. Edited by H. U. Bergmeyer. New York \& London: Academic Press.

MEIBERG, J. B. M. (1979). Metabolism of methylated amines in Hyphomicrobium spp. Ph.D. thesis, University of Groningen, The Netherlands.

Meiberg, J. B. M. \& HARDER, W. (1976). Aerobic and anaerobic degradation of trimethylamine and dimethylamine by Hyphomicrobium X. Proceedings of the Society for General Microbiology 4, 45.

Meiberg, J. B. M. \& Harder, W. (1978). Aerobic and anaerobic metabolism of trimethylamine, dimethylamine and methylamine in Hyphomicrobium X. Journal of General Microbiology 106, 265-276.

Michaelis, L. \& Granick, S. (1943). The polymerization of the free radicals of the Wurster Dye type: the dimeric resonance bond. Journal of the American Chemical Society 65, 1747-1755.

Michaelis, L. \& Hill, E. S. (1933). Potentiometric studies on semiquinones. Journal of the American Chemical Society 55, 1481-1495. 
MYers, P. A. \& ZATMAN, L. J. (1971). The metabolism of trimethylamine $N$-oxide by Bacillus PM6. Biochemical Journal 121, 10P.

Nash, T. (1953). The colorimetric estimation of formaldehyde by means of the Hantzsch reaction. Biochemical Journal 55, 416-421.

STEenKaMP, D. J. \& GalluP, M. (1978). The natural flavoprotein electron acceptor of trimethylamine dehydrogenase. Journal of Biological Chemistry 253, 4086-4089.

Steenkamp, D. J. \& Mallinson, J. (1976). Trimethylamine dehydrogenase from a methylotrophic bacterium. I. Isolation and steady-state kinetics. Biochimica et biophysica acta 429, 705719.

Steenkamp, D. J., Kenney, W. C. \& Singer, T. P. $(1978 a)$. A novel type of covalently bound coenzyme in trimethylamine dehydrogenase. Journal of Biological Chemistry 253, 2812-2817.
Steenkamp, D. J., McIntire, W. \& Kenney, W. C. $(1978 b)$. Structure of the covalently bound coenzyme of trimethylamine dehydrogenase. Evidence for a 6-substituted flavin. Journal of Biological Chemistry 253, 2818-2824.

Steenkamp, D. J., Singer, T. P. \& Beinert, H. $(1978 c)$. Participation of the iron-sulphur cluster and of the covalently bound coenzyme of trimethylamine dehydrogenase in catalysis. Biochemical Journal 169, 361-369.

Steenkamp, D. J., Beinert, H., Mcintire, W. \& SINGER, T. P. (1978d). Reaction mechanism of trimethylamine dehydrogenase. In Mechanisms of Oxidizing Enzymes, pp. 127-141. Edited by T. P. Singer \& R. N. Ondarza. Amsterdam: Elsevier.

Weber, K.; Pringle, J. R. \& Osborn, M. (1972). (1) Measurement of molecular weights by electrophoresis in SDS-acrylamide gel. Methods in Enzymology 26, 3-27. 